\title{
Znaczenie misji
}

\section{przedsiębiorstwa i jej wpływ na kompetencje przywódcze}

\author{
Dr inż. Barłomiej Moszoro | Zachodniopomorski Uniwersytet Technologiczny \\ | Bartlomiej.Moszoro@zut.edu.pl
}

\section{Abstrakt}

Cel

Celem artykułu jest przedstawienie problematyki misji przedsiębiorstwa i związany z nią problem przywództwa.

\section{Metodologia}

Badania literatury przedmiotu zarówno zagranicznej, jak i krajowej. Analiza literatury wskazała na fakt, że firmy często wkładają większy wysiłek w sformułowanie misji aniżeli w jej rozpowszechnianie lub uzyskanie poparcia dla niej wśród pracowników. Następnie przedstawiono wyniki przeprowadzonych ankiet i dyskusji panelowej.

\section{Ograniczenia badawcze}

Ograniczeniem tych wniosków może być pilotażowy aspekt tych badań.

\section{Wnioski}

Badania ankietowe oraz dyskusja panelowa opisane w artykule potwierdziły zasadność tezy dotyczącej skupienia się firm na samym sformułowaniu misji. Wykazały też konieczność formułowania misji przedsiębiorstw w sposób klarowny i wspólny dla wszystkich pracowników. 


\title{
Oryginalność
}

\begin{abstract}
W Polsce brakuje badań na temat misji przedsiębiorstwa. Niniejszy artykuł potwierdza też istotną rolę przywódcy w sformułowaniu misji i potrzebę dogłębniej analizy empirycznej wynikającą z wysokich wobec niego oczekiwań stawianych obecnie ze strony społeczeństwa.
\end{abstract}

\section{JEL: M12}

\section{Wprowadzenie}

Przedsiębiorstwa pełnią w społeczeństwie istotną funkcję nie tylko jako podmiot, który czerpie zyski, ale także jako dostarczyciel określonych i oczekiwanych przez to społeczeństwo wartości. Większość przedsiębiorstw określa kluczowe wartości w misji. Jest ona swoistą deklaracją tożsamości organizacji, zarówno wobec pracowników, jak i interesariuszy spoza organizacji.

Rola przedsiębiorstwa nie kończy się jednak na opracowaniu misji. Kadra menedżerska odpowiada za jej skuteczne realizowanie przez działania operacyjne. Wymaga to zarówno przełożenia wybranych wartości na zestaw kompetencji charakteryzujących dane przedsiębiorstwo (np. kreatywność, elastyczność, zorientowanie na klienta), jak i zainspirowania pracowników, aby działali zgodnie z nimi. Zadanie to spoczywa na przywódcach.

W artykule podjęto dwie kwestie: co powinna zawierać misja przedsiębiorstwa oraz jakie są pożądane kompetencje przywódcze, aby realizować tę misję.

\section{Misja jako przypomnienie o celu istnienia przedsiębiorstwa - rozważania teoretyczne}

Założenie, że celem przedsiębiorstwa jest maksymalizacja zysku, można uznać za pomysł, którego korzenie sięgają teorii bogacenia się narodów Adama Smitha. Smith uważał, że przedsiębiorcy poszukujący własnego interesu pomagają społeczeństwu efektywnie funkcjonować (por. Canals 2010). Niemniej jednak teoria ta, której całościowa analiza wykracza poza ramy niniejszego opracowania, nie posiada - z punktu widzenia zarządzania - dostatecznych uzasadnień. Na przykład H. Simon - już w zaczątkach nauki o zarządzaniu - utrzymywał, że zadaniem menedżerów nie jest osiągnięcie wyników maksymalnych, lecz zadowalających, chociażby z powodu ograniczeń w działaniu racjonalnym (bounded rationality) oraz niepełnych informacji, które na takie działanie nie pozwalają (Simon 1947). Maksymalizacja zysku jako taka ani nie określa jasnych parametrów czasowych, jak powinno być przy każdym problemie decyzyjnym, ani nie wyjaśnia kwestii interesów udziałowców czy innych podmiotów zainteresowanych suk- 
cesem przedsiębiorstwa (Freeman 2010). Ostatecznie takie postępowanie przyniosłoby firmom krótkoterminowe korzyści finansowe, jednak kosztem oczekiwań klientów, co miałoby wpływ na wyniki osiągane w długim okresie (Porter, Kramer 2011).

W naukach o zarządzaniu określanie celu istnienia przedsiębiorstwa łączone jest z pojęciem misji. Początkowo definicja misji była odpowiedzią na pytania „Czym jest nasze przedsiębiorstwo i czym być powinno? Jaki jest najważniejszy cel przedsiębiorstwa?” (Drucker 1974). Do dziś ta definicja niewiele się zmieniła, dodawano jedynie nowe elementy, ale nie zmieniono jej istoty. Na przykład. R. Clark mówił o oferowanym produkcie, stosowanej technologii i rynku obsługiwanym przez przedsiębiorstwo (Clark 1986), a A. Campbell i L. Nash zestawili pojęcie misji z takimi pojęciami jak: strategia, wartości przedsiębiorstwa, polityka i standardy postępowania (Campbell, Nash 1992).

Od końca lat 80. w definicji misji zaczęły się pojawiać również takie pytania jak: „Kim jesteśmy? Co staramy się zrobić? Komu służymy? Od czego lub od kogo zależy nasz sukces?” (Muckian, Arnold 1989). P. Senge dodał pytania: „Po co istnieje organizacja? Jaki wkład wnosi przedsiębiorstwo?” (Senge 1998). W wielu organizacjach przyjęto również, powstałą w połowie lat 80., koncepcję interesariuszy, co sprawiło, że w deklaracjach misji zaczęto uwzględniać interesy różnych zainteresowanych działalnością przedsiębiorstwa, grup. Dla Cardony, i Reya oraz Freemana misja stanowi kompendium wartości, jakich oczekują klienci i inni interesariusze przedsiębiorstwa (Freeman 2010; Cardona, Rey 2009: 75).

Misja i wartości stanowią jedną całość, na której opiera się kultura organizacyjna przedsiębiorstwa. Jeżeli misja jest celem, który wyznacza kierunek działania, to wartości należy uznać za kryteria i wskazówki w procesie podejmowania decyzji dotyczących najbardziej odpowiedniego sposobu postępowania w konkretnej sytuacji. Wartości wskazują, jak należy realizować misję. Właściwy wybór wartości - takich, które są spójne z misją - stanowi ważną część tego, co Cardona i Rey (2009: 80) określają „intrategią”.

Dla M. Portera i M. Kramera przedsiębiorstwo istnieje po to, aby wspólnie ze społeczeństwem tworzyć wartość, która łączy rozwój społeczeństwa z rozwojem gospodarczym (Porter, Kramer 2006). Każda firma powinna podejmować decyzje w kontekście tej wspólnej wartości. Takie podejście zapewnia większą innowacyjność i stały rozwój, co przyniesie więcej korzyści całemu społeczeństwu.

Jakie wartości mogą zatem znaleźć się w misji przedsiębiorstwa? Według Cardony i Reya kluczowe są cztery zrównoważone kategorie wartości:

- biznesowe - związane z działalnością biznesową i osiąganiem zysku, np. wytrwałość, skuteczność, profesjonalizm, zorientowanie na wyniki;

- racjonalne - wartości związane z jakością w relacjach interpersonalnych, np. komunikacja, praca zespołowa, szacunek dla ludzi; 
- rozwojowe, takie jak innowacyjność, kreatywność, uczenie się czy nieustanne doskonalenie;

- związane z wkładem na rzecz innych (m.in. działania z zakresu CSR).

Wypracowanie wartości i zarządzanie zmianą kultury organizacyjnej należy do najtrudniejszych zadań menedżerów. Z jednej strony w przedsiębiorstwach należy podtrzymywać i wzmacniać system wartości, dzięki którym osiągają one sukces, z drugiej zaś należy ujawniać i eliminować wartości negatywne i tworzyć plany działania mające na celu znalezienie środków zaradczych. Skuteczny przywódca powinien zatem stworzyć system wartości stanowiący podstawę dla opracowania wspólnie z pracownikami misji oraz angażujący pracowników w realizację jednolitej strategii. Strategia zaś powinna posiadać mierzalne cele i opierać się na zasobach materialnych i ludzkich firmy, znajdując odzwierciedlenie na poziomie operacyjnym (zob. rysunek 1). System ten wywiera duży wpływ na menedżera i stanowi proces przekształcenia menedżera w przywódcę inspirowanego misją. Opiera się na: zaangażowaniu, współpracy (czyli identyfikacji grona wewnętrznych klientów, budowaniu porozumień, proaktywnym monitorowaniu i ocenie usług) i wprowadzaniu zmian. Zmiana jest traktowana nie jako cel, ale jako środek, a poszukiwanie doskonałości jest procesem ciągłym i nieustającym. Taki model wartości sprzyja ciągłemu ulepszaniu kompetencji kadry oraz kreowaniu nowych przywódców. Z tego powodu „każdy proces wdrażania systemu zarządzania przez misję musi być poparty rzetelnym i solidnym programem szkolenia z zakresu przywództwa i coachingu" (Cardona, Rey 2009: 144).

\section{Rysunek 1 | Zarządzanie poprzez misję}

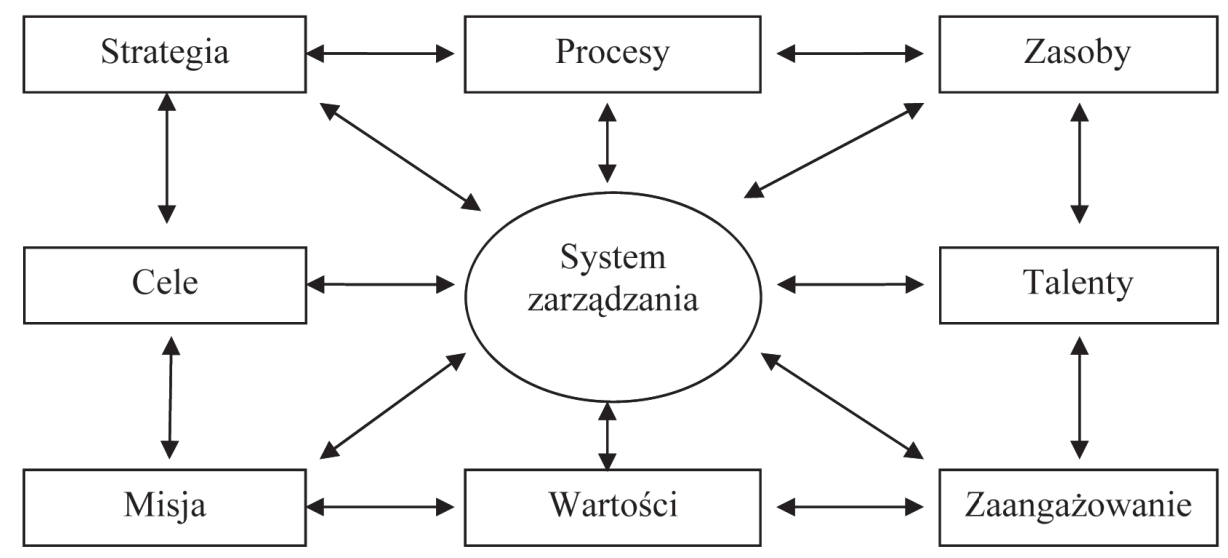

Źródło: Cardona, Rey (2009: 42).

\section{Misja w praktyce działania przedsiębiorstw - przegląd wyników badań}

Misja jest ostatnio często podejmowanym tematem, jak również przedmiotem badań empirycznych, które warto rozwijać zwłaszcza w czasie kryzysu gospodarczego i finansowego (King et al. 2010; Canals 2010; Zollo, Freeman 2010). Obszerne badania nad zawartością misji (content ana- 
lysis) prowadzone w Stanach Zjednoczonych na wyselekcjonowanych 300 przedsiębiorstwach z list: „Fortune 2000”, „The Forbes 200”, „The Inc. 500” i „The 10 Best Companies to Work for in America" wykazały, że przedsiębiorstwa, formułując misję, nadużywają pewnych zwrotów. Oznacza to, że bardzo krótkie zdania przeładowuje się wiele znaczącymi pojęciami, które są powtarzane przez niemal wszystkie firmy. Dziesięciu procentom nagłówków można było przypisać siedemdziesiąt osiem procent treści w nich zawartych Pięć najczęściej stosowanych zwrotów w treści misji to: misja, wizja, wartości, zasady i strategie. Oznacza to, że większość przedsiębiorstw stosuje tradycyjne sformułowania i rzadko podejmuje próby kreatywnego i unikatowego ich redagowania. Termin „zwrot/wartość dla udziałowców” był stosowany 255 razy na 489 analizowanych przypadków. Wnioski autorów badań sprowadzają się do przestrzegania menedżerów przed modnymi hasłami i politycznie poprawną terminologią, jako że takie formalne określanie misji nie wiąże się z jej stosowaniem w praktyce (Cady et al. 2011).

Cennych informacji dotyczących sformułowań misji przedsiębiorstw dostarczają również inne badania, analizujące 500 najlepszych firm z listy „Fortune”. W efekcie porównań między 2008 a 2000 r. wynika, że w 2008 r. 30\% przedsiębiorstw dodało do swojej misji dewizę związaną z etycznym postępowaniem i etyką w ogóle, podczas gdy w 2000 r. jedynie $3 \%$ firm odważyło się na takie sformułowania. Ponadto bardzo popularne stały się stwierdzenia typu: być globalnym dostawcą jakiegoś dobra lub usług oraz prowadzić wysokiej jakości usługi lub produkować i sprzedawać towary o wyjątkowej wartości dla klienta. Klienci byli na ogół najczęściej wskazywaną grupą interesariuszy, a słowo „społeczność” często pojawiało się w sformułowaniach misji (King et al. 2010).

W Polsce badania dotyczące misji przedsiębiorstw należą do rzadkości. Cenne wnioski na ten temat wnoszą badania z sektora energetycznego. Wśród polskich firm w sektorze energetycznym niemal powszechne jest przyjęcie deklaracji misji i wartości, zdeterminowane międzynarodowymi standardami CSR dla tej branży. Zgodnie z wynikami badania ankietowego jedynie 13\% ankietowanych przyznało, że nie zdefiniowało i nie przyjęło misji ani kanonu wartości, aż 63\% stwierdziło, że deklaracja o tym charakterze została u nich przyjęta, a kolejnych $25 \%$ dodało, że poza przyjęciem misji prowadzi audyty w obszarze zasad i wartości przyjętych w firmie lub realizuje szkolenia celem upowszechniania wiedzy w tym zakresie wśród pracowników. Przyjęcie deklaracji na temat CSR nie przekłada się jednak automatycznie na przejście przez firmę na poziom trudniejszej, dojrzałej komunikacji i kompleksowego podejścia do kwestii odpowiedzialności społecznej i zrównoważonego rozwoju (Polski sektor energetyczny w świetle międzynarodowych standardów CSR Badanie 2011: 9).

Badania firmy PricewaterhouseCoopers „Zdrowy rozwój”, prowadzone we współpracy z Inicjatywą Firm Rodzinnych, PKPP Lewiatan oraz Stowarzyszeniem Emitentów Giełdowych w małych, średnich i dużych przedsiębiorstwach, wykazały duże braki w zakresie samego zarządzania strategicznego. W rankingu wskazywanych celów firm elementy krótkookresowe (dochody, zyski) zdecydowanie dominowały nad elementami długofalowymi, takimi jak budowa trwałych więzi z klientami, partnerami, pracownikami i otoczeniem. Mimo że firmy często przygotowują 
plany strategiczne, także w postaci sformalizowanej, mają one zazwyczaj charakter ogólny i nie są oparte na solidnej analizie mocnych i słabych stron (Orłowski et al. 2010: 45). Prawdopodobnie brak jasnej wizji funkcjonowania i rozwoju (w większości przedsiębiorstw sektora MSP) stanowi w dłuższej perspektywie poważne zagrożenie, ponieważ nie zachęca do podejmowania działań decydujących o długookresowej konkurencyjności. Niestety większość przedsiębiorstw zdaje się nie dostrzegać rangi problemu, deklarując, że brak planów rozwojowych wynika z poczucia braku sensu planowania. Takie krótkookresowe spojrzenie determinuje również politykę w zakresie pozyskiwania nowych pracowników (Orłowski et al. 2010: 46).

O roli przywódcy we wprowadzaniu w życie misji przedsiębiorstwa wypowiadają się badacze amerykańscy (Cady i inni 2011: 63). Potwierdzili oni hipotezę, że menedżerowie zazwyczaj poświęcają mały odsetek swego czasu na podjęcie wysiłku zrozumienia misji i jej realizacji, a w zamian za to większość czasu zabiera im rozpisywanie i dokumentowanie misji przedsiębiorstwa. Wskazuje to na często spotykany w przedsiębiorstwach dysonans pomiędzy aspiracjami zawartymi w misji a ich realizacją. Odbiegające od misji działania przedsiębiorstw pokazują brak przywództwa w najistotniejszym momencie, jakim jest wprowadzanie w praktyce fundamentalnych założeń funkcjonowania przedsiębiorstwa (Cady et al. 2011: 65).

\section{Kompetencje przywódcze w sformułowaniu i wdrażaniu misji - wyniki badań i wnioski z projektu Czas na rozwój. Człowiek i biznes w społeczeństwie obywatelskim}

Tematyka odpowiedzialnego przywództwa stanowiła przedmiot badań ankietowych i dyskusji panelowej w ramach drugiej interdyscyplinarnej konferencji Czas na rozwój. Człowiek i biznes w społeczeństwie obywatelskim. W badaniach ankietowych wzięło udział 32 respondentów, natomiast w dyskusji panelowej 9 osób oraz moderator - autor niniejszego artykułu. Wśród uczestników znalazły się osoby reprezentujące różne środowiska (biznes, edukacja, administracja publiczna), pełniący różne funkcje w organizacjach (przełożony, podwładny, właściciel), z firm zarówno państwowych, jak i prywatnych, małych i średnich, oraz jedna osoba pracująca w dużej korporacji. Wszystkie osoby biorące udział w tych badaniach miały wykształcenie wyższe, zarówno z nauk ścisłych, jak i humanistycznych. Wśród uczestników były też osoby z tytułem doktorskim.

W trakcie sesji panelowej na pytanie „Czy każde przedsiębiorstwo posiada misję w służbie społeczeństwa? Co misja powinna wyrażać? Jaki rodzaj wartości powinna zawierać?” uczestnicy panelu odpowiedzieli następująco:

- misja powinna powstać wspólnie, tzn. przy udziale wszystkich pracowników; powinna odzwierciedlać wartości akceptowane przez wszystkich w przedsiębiorstwie;

- wartości powinny mieć wymiar zarówno biznesowy, jak i społeczny;

- misja powinna być normą w przedsiębiorstwie, pracownicy powinni utożsamiać się z nią; przejawiać postawy i zachowania zgodne z wynikającymi z misji wartościami; 
- treść misji powinna być wiarygodna;

- misja powinna odzwierciedlać oczekiwania nie tylko pracowników, ale również lokalnej społeczności i innych interesariuszy;

- misja jest deklaracją „na zewnątrz” - tym, co przedsiębiorstwo chce publicznie oświadczyć;

- kluczowymi wartościami powinny być prawda, jakość i uczciwość;

- $\quad$ w treści misji warto zawrzeć również sposoby osiągania pożądanych wartości.

Cennych wniosków dostarczyły również wyniki badań ankietowych zrealizowanych podczas konferencji, dotyczących wartości składających się na misję przedsiębiorstwa. Okazało się, iż ankietowani najczęściej wskazywali wartości biznesowe (zob. tabela 1), związane z działalnością biznesową i osiąganiem zysku, np. skuteczność, profesjonalizm, zorientowanie na wyniki (59\% ankietowanych wybrało je jako najważniejsze w hierarchii ważności elementów składowych misji przedsiębiorstwa). Tak wysokie wyniki przemawiają za tym, że w dzisiejszej gospodarce, jakakolwiek by była misja organizacji, nie miałaby ona większego sensu bez spełniania podstawowych kryteriów efektywności i profesjonalnego działania.

Wysokie wyniki otrzymały również wartości rozwojowe, takie jak: innowacyjność, kreatywność, uczenie się, nieustanne doskonalenie (63\% ankietowanych wskazało je na pierwszym lub drugim miejscu). Jest to - zdaniem autora - przyszłościowe podejście do przedsiębiorstwa i do jego funkcji w społeczeństwie.

Wartości racjonalne zostały wybrane na trzecim miejscu. Wśród nich znalazły się: jakość w relacjach interpersonalnych, np. komunikacja, praca zespołowa, a także szacunek do ludzi. Wartości te wydają się warunkiem sine qua non misji każdego przedsiębiorstwa. Nie zostały one wskazane przez respondentów na pierwszym miejscu, jednak oczekuje się ich od menedżerów w każdej sytuacji.

Najrzadziej wymieniane wartości wiązały się z wkładem na rzecz innych, np. działanie na rzecz interesariuszy w większym stopniu niż jest to konieczne z punktu widzenia realizacji celów biznesowych (zadowolenie klientów, zainteresowanie ludźmi, odpowiedzialność społeczna). 56\% ankietowanych wymieniło je dopiero na trzecim lub czwartym miejscu w hierarchii ważności w misji firmy. Pomiędzy tą kategorią a wartościami biznesowymi, które były pierwszą kategorią w rankingu, wystąpiła różnica w sumie ocen ok. 27\% całkowitej oceny. Wskazuje ona na rozpatrywanie odpowiedzialności biznesu raczej w kategoriach zarządzania personelem oraz utrzymania wysokiej efektywności w dostarczaniu wartości oczekiwanych przez klientów niż działalności dobroczynnej. 
Tabela 1 | Rodzaje i hierarchia wartości wchodzących w skład misji przedsiębiorstwa

\begin{tabular}{|c|c|c|c|c|c|}
\hline \multirow{2}{*}{$\begin{array}{l}\text { Rodzaje wartości wchodzące } \\
\text { w skład misji przedsiębiorstwa }\end{array}$} & \multicolumn{4}{|c|}{ Liczba osób, która wybrała daną kategorię jako nr } & \multirow{2}{*}{ 晨 } \\
\hline & 1 & 2 & 3 & 4 & \\
\hline Wartości biznesowe & 19 & 2 & 3 & 6 & 1 \\
\hline Wartości rozwojowe & 7 & 13 & 9 & 1 & 2 \\
\hline Wartości racjonalne & 4 & 9 & 13 & 4 & 3 \\
\hline Wartości związane z wkładem na rzecz innych & 3 & 9 & 5 & 13 & 4 \\
\hline
\end{tabular}

Źródło: opracowanie własne na podstawie badania ankietowego.

Kluczową rolę w procesie definiowania głównych wartości oraz formułowania i realizowania misji przedsiębiorstwa ma do spełnienia przywódca. W trakcie dyskusji panelowej podjęto próbę charakterystyki dobrego przywódcy. Przypisano mu takie atrybuty jak:

- minister (łac.), jako ten kto służy, czuwa z troską o dobro wspólne;

- rozważny i odważny;

- tworzący zasady i dbający o ich przestrzeganie;

- dający poznać siebie i prezentujący zgodność zachowań z głoszonymi sądami;

- mający wiedzę i doświadczenie;

- sumienny, wymagający, wprowadzający dyscyplinę;

- krytyczny wobec siebie;

- potrafiący słuchać;

- rozwijający talenty pracowników oraz zapewniający dalszy rozwój.

Cechy przywódcze zaproponowane w trakcie panelu dyskusyjnego można sklasyfikować w dwie grupy: kompetencje w znaczeniu wymiaru biznesowego (tworzy zasady, posiada wiedzę i doświadczenie) oraz kompetencje związane z „człowieczeństwem” przywódcy (sumienność, rozwaga, spójność zachowań).

Kompetencje przywódcy stanowiły również przedmiot badań ankietowych. Respondentów poproszono o uszeregowanie listy kompetencji uznanych przez Cardonę i Wilkinsona (2010) za najbardziej znaczące w zakresie misji przedsiębiorstwa. Stworzono dzięki temu „własny ranking” kompetencji (zob. tabela 2). Największą liczbę wskazań uzyskały kompetencje interpersonalne, takie jak: umiejętność pracy zespołowej, komunikacji interpersonalnej i motywowania innych. Kompetencja ściśle związana z „człowieczeństwem” przywódcy, jaką jest szczerość postępowania, zajęła szóste miejsce na dziesięć możliwych. Najrzadziej wybierane były nato- 
miast: umiejętność zdobywania informacji na temat firmy (powyżej 90\% ankietowanych nie wybrało tej kompetencji) oraz orientacja na klienta i elastyczność (78\% osób nie zaznaczyło jej wśród 5 najważniejszych).

Tabela 2 | Ranking kompetencji przywódczych o największej roli w realizacji misji przedsiębiorstwa

\begin{tabular}{|c|l|c|}
\hline Ranking & \multicolumn{1}{|c|}{ Kompetencja } & $\begin{array}{c}\text { Pozycjonowanie } \\
\text { kompetencji }\end{array}$ \\
\hline 1 & Umiejętność pracy zespołowej oraz inicjatywa & 75 \\
\hline 2 & Podejmowanie decyzji & 68 \\
\hline 3 & Komunikacja interpersonalna & 62 \\
\hline 4 & Motywowanie innych & 56 \\
\hline 5 & Umiejętność rozpoznania zagrożeń i wykorzystania możliwości & 54 \\
\hline 6 & Szczerość postępowania & 47 \\
\hline 7 & Umiejętności negocjacyjne (wypracowywanie porozumienia) & 33 \\
\hline 8 & Orientacja na klienta & 19 \\
\hline 9 & Elastyczność & 14 \\
\hline 10 & Umiejętność zdobywania informacji na temat firmy & 7 \\
\hline
\end{tabular}

Źródło: opracowanie własne na podstawie badania ankietowego.

Wyniki badań ankietowych oraz dyskusji panelowej prowadzą do wniosku, że przywódca to osoba, której zakres odpowiedzialności zaczyna się wewnątrz przedsiębiorstwa, lecz na tym się nie kończy. Ostatecznie przywódca odpowiada nie tylko przed pracownikami, ale również przed klientami czy społecznością lokalną. Ponadto przyczynia się do tworzenia postaw, które kreują następne pokolenia, zatem jego odpowiedzialność dotyczy również przyszłych pokoleń.

\section{Zakończenie}

Temat misji przedsiębiorstwa oraz kompetencji przywódczych mających kluczowe znaczenie dla jej realizacji wzbudził - jak się okazało w trakcie dyskusji panelowej - duże zainteresowanie. W obliczu kryzysu finansowego nabiera jeszcze większego znaczenia, szczególnie że jednej z głównych przyczyn kryzysu upatruje się w braku etycznych zachowań przywódców.

Istnieje potrzeba formułowania misji przedsiębiorstw w sposób klarowny i wspólny dla wszystkich pracowników. Przedsiębiorstwo nie istnieje jedynie po to, aby generować zyski. Uczestnicy konferencji wśród głównych wartości wskazali bowiem wartości zarówno biznesowe, jak i rozwojowe. Oznacza to, że przedsiębiorstwom powinno zależeć nie tylko na efektywności, lecz także na innowacyjności. Liczą się zarówno wyniki ekonomiczne, jak i rozwój pracowników. 
Analiza wyników badań zagranicznych przedsiębiorstw wskazuje, że firmy często wkładają większy wysiłek w sformułowanie misji niż w jej rozpowszechnianie lub uzyskanie poparcia dla niej wśród pracowników. Badania ankietowe oraz dyskusja panelowa opisane w artykule potwierdziły zasadność tych obaw. Wskazały też na istotną rolę przywódcy i wysokie oczekiwania wobec niego ze strony społeczeństwa. Od przywódcy oczekuje się wspierania pracowników w rozwoju kompetencji, które najlepiej odzwierciedlają wartości wynikające z misji przedsiębiorstwa. Od tego, czy menedżerowie okażą się prawdziwymi przywódcami, zależy sukces w realizacji misji przedsiębiorstwa, a tym samym spełnienie oczekiwań szerokiego grona interesariuszy.

B i b l i 0 g

Adair J. (2010) Kształtowanie liderów. Siedem zasad rozwijania zdolności przywódczych. Warszawa: Oficyna Wolters Kluwer.

Cady S.H., Wheeler J.V., DeWolf J., Brodke M. (2011) Mission, Vision, and Values: What Do They Say. Organization Development Journal, No. 1, Vol. 29, s. 63-78.

Campbell A., Nash L. (1992) A sense of Mission: Defining Direction for the Large Corporatin. New York: Addison-Wesley.

Canals J. (2010) Rethinking the firm's mission and purpose. European Management Review, No. 7, s. 195-204.

Cardona P., Rey C. (2009) Zarządzanie poprzez misję. Kraków: Oficyna Wolters Kluwer.

Cardona P., Wilkinson H. (2010) Growing as a leader. Pamplona: Eunsa.

Clark R. (1986) Making the Corporate Mission Possible. CA Magazine, nr 6(119).

Drucker P. (1974) Management: Task, Responsibilities, Practices. New York: Harper \& Row.

Freeman E. (2010) Managing for Stakeholders: Trade-offs or Value Creation. Journal of Business Ethics, nr 96, s. 7-9.
Havard A. (2011) Etyka przywódcy. Trening doskonalenia osobowości. Gdańsk: MSM Studio.

King D., Case C., Premo K. (2010) Current mission statement emphasis: be ethical and go global. Academy of Strategic Management Journal, No. 2, Vol. 9, s. 71-87.

Moss Kanter R. (2011) Czas na pełną odpowiedzialność. Harvard Business Review Polska, grudzień 2010-styczeń 2011.

Muckian M., Arnold M. (1989) CEO Network '89. Credit Union Management, nr 12.

Orłowski W. et al. (2010) Procesy inwestycyjne i strategie przedsiębiorstw w czasach kryzysu. Warszawa: PARP.

Porter M., Kramer M. (2006) Strategy And Society: The Link Between Competitive Advantage And Corporate Social Responsibility. Harvard Business Review, December.

Porter M., Kramer M. (2011) Creating Shared Value. How to reinvent capitalism - and unleash a wave of innovation and growth. Harvard Business Review, January-February, s. 2-17.

Senge P. (1998) The Practice of Innovation. Leader to Leader, nr 9 .

Zollo M., Freeman E. (2010) Re-thinking the firm in a postcrisis world. European Management Review, nr 7, s. 191-194. 